\title{
Türk Sineması’nda Din İmgesi Üzerine Din Sosyolojisi Açısından Bir Bakış Denemesi
}

Halil UZDU ${ }^{(*)}$

\section{$\ddot{O} \mathbf{z}$}

Türk Sinemas1, yüzyılı aşkın tarihinde toplumsal durumu perdeye yansıtan bir ayna olmasının yanında, aynı zamanda toplumsal değişim ve dönüşümlere de tanıklık etmiş̧ir. Bu itibariyle Türk filmleri çekildiği dönemin toplumsal yapısını anlayabilmek için iyi bir imkân olarak kabul edilebilir. Zira sinema, içinden çıktı̆̆ 1 toplumun sosyal, siyasal, kültürel ve ekonomik durumu hakkında bir fikir verme kapasitesine sahip teknolojik bir imkândır. Bu çalışmanın amacı da din, toplum ve Türk Sineması üzerine din sosyolojisi bağlamında bir bakış denemesidir.

Anahtar Kelimeler: Türk Sineması, Kitle İletişimi, Din, Toplum, Din Sosyolojisi

\section{At A Glance to An Image of Religion on Turkish Cinema Trial in Terms of Sociology of Religion}

\section{Abstract}

Turkish Cinema has been reflecting the social status to the the screen like a mirror and also being witnessed the social changes and transformations for more than a century. The movies that was shot provide us a good opportunity to understand the social structure of that period. Because the cinema is technological opportunity to give ideas about the social, political, cultural and economic status of that society. The aim of this study is a point of view on religion, society and Turkish Cinema in the name of the sociology of religion.

Keywords: Turkish Cinema, Mass Communication, Religion, Society, Sociology of Religion

* Bu makale SDÜ SBE'de Felsefe ve Din Bilimleri ABD'da Prof. Dr. Adem Efe danışmanlığında Halil UZDU tarafından hazırlanan "Türk Sineması'nda Din ve Modernleşme (1960-1975)" başlıklı doktora tezinin ikinci bölümünden kısaltılarak alınmıştır.

** Öğr. Gör. Dr., Afyon Kocatepe Üniversitesi, Afyon MYO (huzdu@hotmail.com) 


\section{Giriş}

Gazete, dergi, radyo, televizyon ve sinema başta olmak üzere çeşitli kitle iletişim araçları vasıtasıyla topluma aktarılan bilgilerin, toplumun sosyal ve kültürel hayatında önemli bir yere sahip olduğu muhakkaktır. Güçhan'ın ifadesiyle sinemada da dâhil olmak üzere bütün kitle iletişim araçları adeta "resmi olmayan güçlü bir eğitim kaynağıdır", bu nedenle de içeriği ne kadar zararsız görünürse görünsün toplumun değer yargılarından, ideolojik ve politik eğilimlerinden uzak değildir. ${ }^{1}$ Dolayısıyla bir kitle iletişim aracı olarak sinemanın da topluma neyi anlattı $\breve{g} 1$, nasıl anlattı $\breve{g} 1$, bütün bir toplumu nasıl etkilediği ve toplumsal hayata yansımalarını, filmin üretildiği dönemin tarihsel ve toplumsal koşullarından bağımsız düşünmek mümkün değildir. ${ }^{2}$

Sinema, tek tek bireylerin algılarından toplumun genelini etkileyen bir sanat olarak, karanlık bir salonda yani sinema salonunda kalabalık bir seyirci kitlesine hitap eder. Bu seyirci kitlesinin yaşamı anlama, anlamlandırma, hayatının içinden değerlere bakma, kadın, erkek, cinsellik gibi yaşamsal konuları algılama biçimini etkileyebilir. Dolayısıyla sinema perdesinde akan görüntüler, onu izleyen topluluk üzerinde belirli bir etkiye sahiptir. Bu etkilerden biri de izleyicinin perdede gördügü filmin bir parçası olarak verilen değerlerin içinde yaşaması ve o değerlerin yaşanış biçimine bizzat katılmasıdır. Bir bakıma izleyici karanlık bir salondan baktığı öteki yaşamın canlı bir parçası olur. Bu bağlamda sinema bizim hayatımızdan değerler taşıdığı gibi sanatsal okuma biçimine dayalı olarak yeni değerlerin de üreticisi konumundadır. Sinema, ayn zamanda toplumu okuma konusunda sosyal bilimcilere ışı tuttuğu gibi toplumsal sorun ve çelişkileri de yansıtma imkânına sahiptir. $^{3}$

Genellikle "yedinci sanat" olarak isimlendirilen ve Monaco'nun da "kayıt sanatları" nın bir türü̈ ${ }^{4}$ olarak isimlendirdiği sinema, yaygınlığ ve kişileri etkileme kapasitesi ile diğer sanatlardan farklı bir konumda değerlendirilmeyi hak etmektedir. Çünkü sinema, sadece bir sanat uğraşısı olmanın ötesinde, içinden çıktı̆̆ 1 toplumun kültürel yapısını en iyi yansıtan bir kanal, bir imkân olarak, toplumsal hayatın anlaşılmasında başvurulabilecek zengin bir kaynak olarak değerlendirilebilir. Bu haliyle sinemanın öncelikle bir eğlence aracı, sonrasında ise toplumsal ve kültürel bir araç olarak toplumdaki yerini aldı $\breve{g} 1$ ifade edilebilir.

1 Güçhan, Gülseren, Toplumsal Değişme ve Türk Sinemast, İmge Kitabevi, Ankara, 1992, s 69.

2 Kırel, Serpil, Yeşilçam Öykü Sineması, Babil Kitap, İstanbul, 2005, s 137.

3 Karakaya, Handan, Türk Sinemasında Din Adamı Tiplemesi, (Yayınlanmamış Yüksek Lisans Tezi), Firat Üniversitesi Sosyal Bilimler Enstitüsü, Elazığ, 2008, s 15. 
1950'li yıllara kadar Türkiye'de sinema, yetersiz altyapı, tek kişi hâkimiyeti ve benzer nedenlerle maalesef kültürel olgu olarak toplumsal hayatta belirgin bir etkinlik gösterememiştir. Teknik, içerik ve sanat anlamında yetersizliklerin yanında bu yıllarda çekilen film konuları dikkate alındı ğında hissedilmeyen toplumsal etkinliğin sebepleri daha da anlaşılır hale gelmektedir. Çünkü bu dönemde çekilen Türk filmlerinde aile, kadın, evlilik gibi toplumsal değerlere geleneksel Türk toplum yapısında karşılığı bulunmayan batılı formlarla yaklaşılımıştır. ${ }^{5}$ Batılı bir formda ortaya çıkan Türk Sineması'nın, yerli bir karakter, üslup ve özgün bir gelenek oluşturamaması da, toplum-sinema etkileşimi açısından etkisizliğinin başlıca nedenleri arasındadır.

\section{Türk Sinemasında Din ve Toplum}

Bir sanat olarak sinemanın içinden çıktı̆̆ toplumun değerlerinden bağımsız düşünülmesi sinema ve toplumsal etkileşim açısından oldukça zordur. Tabiatıyla Türk Sineması da Cumhuriyet tarihinin siyasal, sosyal, kültürel ve ekonomik seyrini takip eden bir düzen içerisinde gelişim göstermiştir. Cumhuriyetin ilk yıllarından itibaren "sekülarist ideoloji" çerçevesinde din ve devletin ayrımıyla başlayan laik siyasal örgütlenme; hayatı, önce bireysel ve kamusal şeklinde ikiye ayırmış, hayatı bir bütün olarak değerlendiren dinsel görüşün aksine dini, kamusal alandan tamamen tecrit ederek bireysel çerçeve ve vicdanla sınırlamıştır. Zaten "Cumhuriyet rejiminin yaratmak istediği yeni birey, rasyonel, din karşıtı ve bütün meselelere entelektüel açıdan ve tarafsız yaklaşacak kişiydi" ve yegâne amaç dinin toplum ve siyasal hayat üzerindeki zincirlerini kırmaktı. ${ }^{6}$

Cumhuriyet dönemi din politikaları, toplumsal hayatı maddi ve manevi hayat şeklinde tanımlayarak dinin "bireyin vicdani sorumluluğu" çerçevesindeki tanımını ön plana çıkarmıştır. Karpat'a göre bu iman ve din tartışmalarının tabii sonucudur. Çünkü mezkûr tartı̧̧malarda iman, Allah, peygamber ve öğretilerine içten/ samimi bağlılıkla tanımlanırken; din ise insan yapısı bir organizasyon ve inancın yayılmasında manipüle edilebilen kimlikler olarak tanımlanmışlardır. Haliyle

4 Monaco, James, Bir Film Nasıl Okunur, (Çev. Ertan Yılmaz), Oğlak Yayıncılık, İstanbul, 2011, s 42.

5 Yenen, İbrahim, Toplumsal Tezahürleri Bağlamında Türk Sinemamsında Din Dindarlık ve Din Adamı Olgusu, (Yayınlanmamış Doktora), Tezi, Anakara Üniversitesi Sosyal Bilimler Enstitüsü, Ankara, 2011, s. 17.

Tunalı, Dilek, Batıdan Doğuya, Hollywood'dan Yeşilçam'a Melodram, Aşina Kitaplar, Ankara, 2006, s. 187.

6 Heper, Metin, Türkiye'de Devlet Geleneği, 3. Baskı, Doğu Batı Yay., Ankara, 2010, s. 120. 
modernleştiriciler, imanı doğal bir manevi yönelim olarak görmek istemektedirler. Ancak onlara göre bu iman, dinin kurumsal ve yasal ayrıntılarında yapılacak düzenlemelerle korunmalı, aralarındaki ilişkiler çağdaş medeniyetin gereklerine uygun hale getirilmelidir. Zira din, sosyal ve siyasal amaçlara göre kullanılabilir ama iman bu tür faaliyetlere alet edilemez. ${ }^{7}$

Türk Sineması'nda din ve toplum ilişkilerini anlamak için Erken Cumhuriyet Dönemi din politikalarına genel olarak değinmek konuyu daha anlaşılır kılabilir. Dinin işlevini belirlemek amaciyla, Cumhuriyetin ilk yönetici seçkinlerinin siyasal ve zihinsel farklılaşmalarını dikkate alan Kılıç, bu seçkinleri "kökten batıcı" ve "liberal batıcı" olarak ikiye ayırmaktadır. "Kökten batıcı seçkinci zihniyet", kısaca ifade etmek gerekirse hayatın bütün alanlarında saf batılılaşma anlayışını temsil etmektedir. Bu zihniyete göre İslam dini, camilere sıra ve org sokulması teklifleri bağlamında Hıristiyanlığın Protestan yorumunu Türkiye'ye uyarlama çabalarına bile konu olabilmiştir. ${ }^{8}$ Dini daha çok bireysel ve vicdani bir kategoriye indirgeyen bu anlayışı, Tanzimat'tan Cumhuriyet'e kadar canlı bir şekilde devam eden "din-ilerleme" tartışmalarında dinin çağdaşlaşma yolunda yavaşlatıcı bir unsur olduğu kanaatinin tepkisel bir dişavurumu olarak değerlendirmek mümkündür. Çünkü "kökten batıcı cumhuriyet seçkinleri" dini, bir iktidar aracı olarak tanımlamış ve belirli vurgularla tanımlanan bu din anlayışını merkezde tutarak hedef seçilen çağdaş medeniyetler seviyesine ulaşma çabalarında onu "çağdaşlaşma karşıtı" bir konuma indirgemişlerdir. Cumhuriyeti kuran iradenin resmi beyanatlarında laikliğin amacının, dini dünya işleriyle olan geleneksel karşıtlığından kurtarmak ve böylece bireylerin vicdanındaki gerçek yerini daha güçlü bir konuma getirme arzusuna rağmen toplumsal hayatın farklı alanlarındaki dinin çağdaşlaşma karşıtı algısının yerleşmesine engel olamamışlardır. Bu haliyle din, bir taraftan modernleşmenin şiddetli isteği, diğer taraftan imparatorluk bakiyesinden miras alınan sorunlar çerçevesinde, çağdaşlaşma karşıtı olarak değerlendirilmiştir. ${ }^{9}$ Sonuç olarak Cumhuriyet Dönemi medeniyet projesinin, din unsurunu devre dışı bırakıp, dini ve dindarları "paranteze alarak" bir modernleşme hamlesi gerçekleştirme amacını gütmekte olduğu ifade edilebilir. ${ }^{10}$

Dinin siyasi, sosyal ve kültürel planlamalar çerçevesinde "paranteze alınmış" bu hali, farklı uygulamalarla sinema alanında da kendisini hissettirmektedir. 1939

7 Karpat, Kemal. H., İslam'ın Siyasallaşması, Bilgi Ü. Yay., İstanbul, 2004, s. 688-699

8 Kılıç, Ahmet Faruk, "Cumhuriyet'in İlk Yıllarındaki Din Politikalarının Şifresi”, http:// www.dem.org.tr/dem_dergi/2/dem2mak3.pdf, (Erişim: 15.02.2015), 2007, s. 18-22.

9 Yenen, a.g.e., s. 31-32.

10 Kara, İsmail, Cumhuriyet Türkiyesi'nde Bir Mesele Olarak İslam, Dergâh Yay. İstanbul, 2008, s. 28. 
yılında filmleri kontrol etmek amaciyla bakanlar kurulu tarafindan kabul edilen ve resmi gazetede yayımlanan "Filmlerin ve Film Senaryolarının Kontrolüne Dair Nizamname"sinin dördüncü maddesi "din propagandası yapan" filmlerin gösterimine izin verilmeyeceğini belirtmektedir. ${ }^{11}$ Dönemin aydınları da, ülke dışından getirilen filmlerde dinin kullanılmasına tepkisel bir tavır geliştirmişlerdir. Örneğin 1935 yılında gösterilen "Şandu- Sihirli Ada" filmiyle ilgili İsmail Hakkı Baltacıoğlu'nun yaptığı yorum dikkat çekmektedir: "Ne garip değil mi, memleket imparatorluğu yıkıyor, hilafeti ve softalı̆̆ 1 yıkıyor, evliyalar mezhebini, adağ yıkıyor, büsbütün laik bir terbiye yolu tutuyor, fakat kapitalistlerin filmleri bizim halkımıza kilise, papaz, büyü, sır, militarist aşısı getiriyor... Otomobil direksiyonunu şoförsüz yürüten, istediği zaman gözden nihan olan istediği zaman tabiatüstü üstatları yardıma çağıran Şandu filmini gördüm... Din propagandası yapan bir softa, büyü yapan bir büyücü, yabanc1 devlet propagandası yapan bir casus ne kadar tehlikeli ise bu filmde o kadar tehlikelidir." ${ }^{12}$ Baltacıoğlu'nun söz konusu bu ifadeleri de göstermektedir ki, sinema toplumsal alanda büyük bir etki ve güce sahiptir. Bu güçlü teknolojik araç eğer kontrol edilmezse çok tehlikeli bir hale gelebilir. Bu ifadeler aynı zamanda sansürcü bir zihniyetin düşüncelerini dile getirmektedir: bir teknolojik imkân olan sinemayı -ya da herhangi bir iletişim aracını- istediğin gibi kullanmak mümkün değilse en azından onun aksi yönde kullanılmasını önlemek gerekir.

\section{1. İlk Dönem Türk Filmlerinde Din ve Toplum}

Türk modernleşmesi sürecinde genelde ilerlemeyi engelleyici unsur olarak değerlendirilen ve manevi alanla sinırlandırılan din, İlk Dönem Türk Sineması'nda da bu sınırlandırmaya uygun olarak "dışlanmış" ${ }^{13}$ bir şekilde değerlendirilmiştir. Aslında bu paralelliği sağlayan unsurlardan birisi, siyasal alanda görülen "köktenci batıcı zihniyetin"14 Türk Sineması'nda da geçerli olmasıdır. Dönemin siyasal ve sanatsal paradigmalarının aynı zeminde buluşmasını sağlayan kişi ise tiyatro yönetmeni, yazar ve oyuncu Muhsin Ertuğrul'dur.

Türk Sineması'nda birçok ilki gerçekleştiren buna rağmen ülkede sinema sanatının gelişmesine engel olmakla da suçlanan Ertuğrul, "sinemada o gün için ihtiyaç duyulan milli konuları ve Kemalist görüşleri ele almadığ 1 , bunun yerine

11 Öztürk, Serdar, Erken Cumhuriyet Döneminde Sinema-Seyir-Siyaset, Elips Kit., Ankara, 2005, s. 65.

12 Abisel, Nilgün, Türk Sineması Üzerine Yazılar, İmge Kitabevi, Ankara, 1994, s. 18.

13 Yenen, a.g.e., s. 198.

14 Kilıç, a.g.m., s. 18-22. 
batıcılığa öykündüğü’” ${ }^{15}$ gerekçesiyle de eleştirilmiştir. Her şeye rağmen Muhsin Ertuğrul yaptığ 1 uyarlamalarla Cumhuriyetin modernleşme projesini benimsemiş ve bu doğrultuda filmler üretmiştir. 1922-1939 yılları arasında çekmiş olduğu 13 filmden ${ }^{16}$ altısı, içerik ve etki itibariyle din ve din adamı öğesi barındırmaktadır. Bunlar; Nur Baba (Boğaziçi Esrarı-1922), Ateşten Gömlek (1923), Ankara Postası (1929), Bir Millet Uyanıyor (1932), Ayranoz Kadısı (1938) ve Bir Kavuk Devrildi (1939) filmleridir. Ertuğrul'un dini unsur bulunduran bu altı filminin konu dağılımına bakıldığında üç tanesinin doğrudan milli mücadeleyi anlattığı görülmektedir. Kurtuluş Savaşı konulu bu filmlerdeki din ve din adamı öğeleri ise temel hikâyenin alt metinlerinde ortaya çıkmaktadır. İki film ise tekke hayatını anlatan "Nur Baba" ve geleneksel Osmanlı saray hayatının konu edildiği "Bir Kavuk Devrildi" dir. Bu haliyle altı filmde rastlanan bulguların özelliği, din olgusunun din adamı karakteri aracılığıyla temsil edilmekte olduğudur. Din adamı karakterleri ise özellikle Kurtuluş Savaşı dönemlerinde -hain, işbirlikçi vs- tasvir edilmektedir.

Muhsin Ertuğrul'un Kurtuluş Savaşı'nı konu edinen eserlerinden ilki, Halide Edip Adıvar'ın aynı adlı romanından uyarlanan "Ateşten Gömlek" (1923) filmidir. Filmin öyküsü İzmir'in işgali sırasında kocası ve çocuğu düşman tarafından öldürülen Ayşe, akrabası Peyami ve Binbaşı İhsan'ın Kuvayi Milliye güçlerine katılması ve bu iki erkeğin aynı kadına âşık olması etrafında gelişmektedir. Sonunda bu üç kişinin de öldüğü filmin asıl özelliği, ilk defa bir Türk filminde MüslümanTürk kadın oyuncuların oynaması olmuştur. ${ }^{17}$ Kadınların sinemaya film seyretmek için bile olsa gitmesinin hoş karşılanmadığı bir dönemde, Müslüman bir kadının aktris olarak sinemada yer alması, önemli bir dönüm noktası olarak değerlendirilmiştir. Reşat Nuri Güntekin 'in "Bir Gece Faciası" adlı eserinden uyarlanan yine Milli Mücadele ile ilgili film olan "Ankara Postası" (1929), filmdeki imam karakteri için "irticanın timsali, düşmanların adamı" tanımlaması ile beğeni toplamıştır. Aynı şekilde Kurtuluş Savaşı konulu "Bir Millet Uyanıyor" (1932) filmi, Nizamettin Nazif Tepedelenlioğlu' nun eserinden uyarlanan ve vatan haini olarak temsil edilen Said Molla ve yandaşlarına karşı Kuvayı Milliyeci olarak mücadele eden bir yüzbaşıyla emir erinin kahramanlık öyküsü üzerine kurulmuştur. Film işgalci güçlerle işbirliği yapan hain din adamı "Molla Said" karakteri ile dikkat çekmektedir. Filmde, dini bir karakterle özdeşleştirilen "hain" sıfatı, dönemin

15 Maktav, Hilmi, "Cumhuriyet'in Sinemacısı Muhsin Ertuğrul", Tarih ve Toplum Dergisi, Kas1m, Say1: 227, İstanbul, 2002, s. 52.

16 Kuyucak Esen, Şükran, Türk Sinemasının Kilometre Taşları, Agora Kitap, İstanbul, 2010, s. 19-33.

17 Kuyucak Esen, a.g.e., s. 48. 
ulusal kimlik inşasına yönelik dinsel kaynaklı itirazların eyleme dönüşmesinin -Şeyh Said isyanı gibi- bir tür izdüşümü olarak okunmak mümkündür. Siyahî bir düşman askerinin bir Türk kadınına tecavüz etmeye yeltendiği sahnede, bu düşman askerinin o dönemin siyasal-kültürel şartları göz önüne alındığında Arapları temsil ettiği ve yeni kimlik inşasının din dışı vurgularla oluşturulmaya çalışılmasının amaçlandığı da ifade edilebilir. Bu film aynı zamanda kendisinden sonra bu tür konularda çekilecek filmlerde özellikle Kurtuluş Savaşı bağlamında "hain din adamı" imajının sürekli kullanılmasında önemli bir rol oynamışır. Neticede Ertuğrul'un Kurtuluş Savaşı'nı farklı alt temalarla işlediği filmleri, gerçekleştirilmeye çalışılan ulus ve ulusal kimlik yaratma çabalarının sinema aracılığıyla temsil edilmesinde rol oynadığ söylenebilir. ${ }^{18}$

Kurtuluş Savaşı konulu eserlerden sonra Ertuğrul'un "Nur Baba" -Boğaziçi Esrart- filmi, hem içerik hem de meydana getirdiği etki itibari ile ayrıca dikkat çeken bir yapımdır. Yakup Kadri Karaosmanoğlu'nun aynı adlı romanından uyarlanan filmin konusu, tekkesine gelen zengin kadınlardan faydalanan, önce ölen şeyhin karısı ile evlenen ve ardından başka kadınlarla ilişki kuran zevk ve şehvet düşkünü bir şeyhin hikâyesine dayanmaktadır. Henüz tekke ve zaviyelerin resmen kapatılmadığı bir dönemde çekildiği için oldukça cüretkâr sayılabilecek bu filmin çekimleri esnasında çeşitli olaylar meydana gelmiştir. Filmin çekim anlarına şahit olan Rakım Çapala olayı şöyle anlatır: "Bir gün stüdyoda çalışırken bir gürültü patırtı koptu. Bir alay Bektaşi dervişi stüdyoya baskın yapmıştı. Bektaşilik aleyhine film çeviriyorlar diye artistlerin üzerine bir yürüyüş yürüdüler, dekorların üzerine bir saldırış saldırdılar ki demeyin gitsin! Bütün dekorlar artistlerin başına geçti. Herkes çil yavrusu gibi bir tarafa dağıldı. Bu arada en çok korkan zavallı Papazyan oldu. Hakkı da yok değildir hani! Arkasındaki Bektaşi urbalarına, çenesindeki takma sakalına rağmen değil Bektaşi, Müslüman bile değildi! Papazyan Unkapanı'ndan bir faytona atladı, evine kaçtı. Ertesi gün... yeniden çalışmalara başlanmıştı. Fakat Papazyan'ın gözü o kadar yılmıştı ki bir daha bu rolü oynamak için kendisini razı etmek mümkün olmadı. Onun son derece korkmuş olduğunu ve tekrar Bektaşi elbisesini sırtına giyemeyeceğini anlayan rejisör, o rolü kendisi oynamak zorunda kald.." ${ }^{19}$

Musahipzade Celal'in eserlerinden uyarlanan "Bir Kavuk Devrildi" (1939) filminde ise, geleneksel Osmanlı saray hayatı etrafından gündelik hayatın hicvedilerek eleştirildiği görülmektedir. Sonuç olarak belirli bir siyasal kültürel yapılanmanın anlamlı bir değere dönüştüğü toplumda film çeken bir yönetmenin, dönem

18 Yenen, a.g.e., s. 35-36.

19 Scognamillo, Giovanni (2003), Türk Sinema Tarihi, 2. Bask1, Kabalcı Yayınları, İstanbul, 2003, s. 46-47. 
şartlarına uygun eserler ortaya koyması beklenilebilen bir durumdur. Ayrıca Muhsin Ertuğrul'un sinemada kullandığı dini unsurlar, aslında kendi dini görüşlerini yansıtmaktadır. Çünkü kendisi, din anlayışını şu şekilde ifade etmektedir: "Biz çok geri kalmış bir milletiz. Bunun milyonlarca başka sebeplerinden vazgeçip de en hakiki saikini ararsak bir din olarak bilgiye tapınmadığımızda buluruz. Dünyada tek bir din vardır, o da "bilgi". Bu bilgiye erişmek için çalışmak en büyük sevap ve ibadettir. Dünyada bir tek mukaddes şey vardır, o da öğreten "kitap". İnsanların bir tane silahı olmalıdır, o da: kalem. Beşer bu büyük gayeye eriştiği gün dünya bir cennettir, insanlar birer dindardırlar, kütüphaneler birer cami, kilise, havra olur."20

Muhsin Ertuğrul'un bu düşünceleri Erken Cumhuriyet dönemi elitlerinin zihinsel yapılarını göstermesi açısından iyi bir örnektir. Zira, Osmanlı'nın son döneminde başlayan modern eğitim sistemi Cumhuriyetle birlikte zirveye ulaşmıştır. Elbette bu modern eğitimin sisteminin en önemli özelliği bilimsel bilginin kutsallaştırıldı ̆̆ı, dini bilginin de dışlandığı hatta yok sayıldığ kim olduğu eğitim sistemiydi. İşte Muhsin Ertuğrul bu sözleriyle pozitivist eğitim sistemin yarattı̆̆ 1 bir insan prototipi olarak modern bilgilerle mücehhez seküler bir birey yaratmanın somutlaşmış halini temsil eder.

\section{Geleneksel Türk Sineması'nda Din ve Toplum}

1922-1950 yılları arasında teknik ve sanat anlamında gelişemeyen Türk Sineması, on yıllık bir geçiş döneminden sonra 1960 yılından başlayarak yeni bir sürece girmiştir. Bu yıllar aynı zamanda Türk toplumunun da siyasi, ekonomik ve kültürel anlamda dönüşüm geçirdiği zamanlara tekabül etmektedir. İç göç, şehirleşme ve sanayileşme, toplumsal hareketliliği arttırmış ve bu canlanma, sinema alanında da yeni anlayış ve arayışların ortaya çıkmasına zemin hazırlamıştır. Ortaya çıkan bu yeni sinema pratikleri, geçmişin toplumsal olgulardan uzak, melodramatik konularından farklılaşarak insanların günlük hayatlarında karşılaştığı sıradan konulara eğilmeye başlamıştır. ${ }^{21}$ Sinema alanında farklılaşan bu eğilim, aynı zamanda din, dindarlık, dini hayat ve din adamı gibi konuların ele alınma biçiminde de görülür. Zira geçmiş yıllarda toplumsal meşruiyeti manevi vicdan sorumluluğuyla tanımlanan din ve dini hayat, 1949 yılında dönemin iktidarı aracılığıyla başlatılan girişimlerle -İmam-Hatip Okulu ve İlahiyat Fakültesi açılması $v b$-, kamusal görünürlüğünü arttırmıştır. Toplumsal hayatta hissedilmeye başlanan bu görünürlük, sinema örneklerinde de karşılık bulmuş ve farklı anlayış ve yorumlama biçimlerine göre temsil edilmiştir. Yenen, "Geleneksel Türk Sinema-

20 Yenen, a.g.e., s. 36.

21 Tunalı, a.g.e., s. 210. 
sı"'22 olarak isimlendirdiği 1960-1996 döneminde yapılan filmlerde din ve din adamı konularını "toplumsal gerçekçi”, "ulusal”, "devrimci", "dinsel (hazretli)" ve "milli" sinema akımları başta olmak üzere çeşitli sinema anlayışlarına uygun çekilen örnek filmleri analiz ederek yorumlamaya çalışmıştır.

Söz konusu dönemin başlangıcı olarak ifade edilen 1960'larda başlayan Türk sinema akımlarının ilki kuşkusuz "Toplumsal Gerçekçi Sinema" akımıdır. Metin Erksan'ın çektiği 1960'da çektiği "Gecelerin Ötesi" filmiyle başladığı kabul edilen bu dönemde ${ }^{23}$ sinemanın toplumsal gerçekliği olduğu gibi yansıtması gerektiği anlayışından hareket edilmiştir. Dolayısıyla din de sosyal gerçeklik olarak sinemada ele alınmıştır. Yenen, söz konusu dönemde çekilen filmlerde ele alınan dini temaya göre bu dönemi "Sosyal Bir Gerçekçilik Olarak Din" 24 şeklinde değerlendirmiştir. 1950'li yıllarla birlikte kurumsallaşmaya başlayan Türk Sineması, 1960 y1lından sonra toplumsal, siyasal, kültürel değişim ve dönüşümlere, iktidar değişikliklerine, çeşitli olaylara ve bunların sebep olduğu yeni konulara duyarlı olmaya başlamıştır. 1960 ihtilalinden sonra yeni bir düşünce ile daha önce yasaklı kabul edilen konu ve sorunlar, sosyal gerçekçiliğin çeşitli eğilim ve biçimleriyle ilk kez bilinçli yaklaşımlarla ele alınmaya başlanmıştır. ${ }^{25} \mathrm{Bu}$ özellikleri ile toplumsal gerçekçi akım, 1950-1960 yılları arasındaki entelektüel canlanmanın ardından 1961 Anayasası'nın sağladığı serbest ortam içerisinde toplumsal ve ekonomik sorunlarını irdelemiş ve temelde marksist eğilimli yazarları çevresinde toplayan Yön dergisinin gelişmeci ve kalkınmacı fikirlerini, sinemaya taşımıştır. ${ }^{26}$ Bu gelişmeci ve kalkınmacı söylem içerisinde dinin konumu ise genelde Marksist din anlayışını yansıtır. Yani din, sınıf mücadelesi şeklinde örgütlenen toplumsal yapıda üst sınıfların alt sınıfları kontrol altında tutmak için geliştirdiği kurumsal bir yapıda ortaya çıkmaktadır. Toplumumuzda din, ezilenlerin ve haksızlığa uğrayan alt sınıfların değil, aksine haksız hâkim sınıfların sahiplendiği bir değer olarak ortaya çıkmaktadır.

Toplumsal gerçekçi filmlerin dramatik gerilim noktaları, modernleşme süreçlerinin ve toplumsal değişmenin oluşturduğu çelişkiler üzerine kurulmasıyla belirginleşmektedir. Çünkü geleneksel ve modern arasındaki çelişki, bütün filmsel anlatıların temel çatışma eksenini oluşturur. Kırsal ortam, geleneksel olanın ser-

22 Yenen, a.g.e.

23 Uçakan, Mesut, Türk Sinemasında İdeoloji, Düşünce Yayınları, İstanbul, 1977, s. 24.

24 Yenen, a.g.e., s.41.

25 Kaplan, Neşe, Aile Sineması Yılları 1960'lar, Es Yayınları, İstanbul, 2004, s. 75.

26 Daldal, Aslı, 1960 Darbesi ve Türk Sinemasında Toplumsal Gerçekçilik, Homer Kitapevi, İstanbul, 2005, s. 93. 
gilendiği kapalı bir dünyayı temsil etmektedir. Geleneksel ilişkilerle sergilenen kırsal dünyada modernleşme, belirli karakterlerle -ögretmen, doktor, mühendis $v b$.- hayatı kolaylaştıran yenilikler olarak ele alınmaktadır. Bu yeni zihniyet değişikliğine karşı çıkanlar da olumsuz karakterler -ă̆a, hoca vb.- aracılı̆̆ıyla temsil edilmiştir. Gelenek ve modernlik çelişkisi üzerine kurgulanan filmlerin inşa ettiği dünyalarda akıl ve bilgi saygın bir yere sahiptir. Bu yıllarda yapılan filmlerin çoğunda akıl/bilgi dışı kategorisindeki büyü yapma, muska yazma, tütsü gibi konular sıkça ele alınmış, özellikle kırsal kesimde hocaların böyle davranışları gündeme getirilerek bu yolla din adamı, kötü niyetli muhtar ve toprak ağası ile birlikte modernleşmenin karşısındaki güçler olarak takdim edilmiştir. ${ }^{27}$

Toplumsal Gerçekçi Sinema'nın takipçisi olarak değerlendirilen "Ulusal Sinema" akımı, 1966 yılından sonra Halit Refĭ̆g, Metin Erksan ve Duygu Sağıroğlu gibi yönetmenler tarafından çeşitli seminer, açık oturum ve sinema yazılarıyla savunulmaya başlanmıştır. Ulusal sinema düşüncesinin kuramsal dayanağı ise 1965'li yıllarda Kemal Tahir ve Sencer Divitçioğlu'nun Marx'ın doğu toplumlarındaki üretim ilişkilerinin Batıdakilerden farklı olduğu tezine dayanarak geliştirdikleri Asya Tipi Üretim Tarzı görüşüdür. ${ }^{28}$ Yenen'in din temasını kullanma biçimine göre "Kültürel Bir Gerçeklik Olarak Din" ${ }^{29}$ şeklinde ifade ettiği Refiğ'in Ulusal Sinema Kuramı, batı karşıtı bir söylemin 1960-1965 yılları arasındaki materyalist ve marksist bakıştan arındırılarak daha yerel, gelenekselci unsurlarla yeniden üretilmesi olarak değerlendirilebilir. ${ }^{30}$ Halit Refiğ Ulusal Sinema akımını hayatı boyunca çektiği filmlerde savunmuş, bu anlayış doğrultusunda sinema düşüncesini şekillendirmiştir. Refiğg, Türk Sineması'nda batıcı akımlara karşı yerlilik düşüncesini ilk defa gündeme getiren sanatçılardan birisidir. Refiğ'in sinema anlayışı, Türk düşüncesinin dil, din, kültür, gelenek, örf-adet gibi önemli unsurlarını Türk insanının gerçek hayatını sinemaya taşımakla tanımlanmaktadır.

Yenen'in din temasını kullanma biçimini "Sinıfl Toplumda Ezilenlerin Umudu Olarak Din"31 biçiminde değerlendirdiği Devrimci Sinema anlayışı, 1965 yılında kurulan "Türk Sinematek Derneği" etrafında toplanan yönetmenler tarafından sinemanın toplum yapısından hareketle değerlendirilmesi gerekliliğini ifade eden bir akımdır. ${ }^{32}$ Devrimci Sinema olarak adlandırılabilecek ilk oluşum, çağdaş ve

27 Yenen, a.g.e., s.42.

28 Coşkun, Esin, Türk Sinemasında Akım Araştırması, Phoenix Yay., Ankara, 2009, s. 56.

29 Yenen, a.g.e., s. 44.

30 Daldal, a.g.e., s. 123.

31 Yenen, a.g.e., s. 48.

32 Uçakan, a.g.e., s.74. 
batı üslubunda film üretimini teşvik eden Türk Sinematek Derneği'nden ayrılan daha radikal bir grup gencin, 1968'de kurduğu "Genç Sinema Hareketi” ve onların aynı adla yayınlanmaya başlayan dergileri olmuştur. Buna göre Türk toplumu, sınıflı bir toplumdur ve Türk sineması da egemen sınıfların değerlerini yansıtan kültürel bir araç haline gelmiştir. ${ }^{33}$ Toplumu üst yapı, alt yapı çatışmasıyla anlamaya ve anlatmaya çalışan bu sinema anlayışında dinin konumu da marksist düşüncelerine uygun olarak işçi, çiftçi, köylü, işsiz gibi toplumsal tabakalaşmanın aşağısında bulunan insanların kendilerini "teskin" ettikleri bir nevi afyon olarak değerlendirilmektedir. Bu durumda din, adaletsizlik üzerine inşa edilmiş ve bu şekilde devam eden toplumun bozuk düzeninin devam etmesine katkı sağlayan bir kuruma dönüşmektedir. ${ }^{34}$

Dinsel film türü, temeli dini konu, kahraman ve mesajlara dayanan filmleri kapsayan bir türdür. Dinsel filmin temeli, dine dayanmakla birlikte farklı türlerde kullanılan özellikleri de içermektedir. Bu tarz sinema, konulara yaklaşım ve işleyiş biçimi ve kullandığ 1 araç-gereçlerin benzerliği sebebiyle tarihsel, biyografik ve destansı filmlerle ortak özelliklere sahiptir. Türk sinemasında da belirli bir dönemde furya halinde oluşan dinsel film ürünleri, kutsal kitaplarda yer alan hikâyeler, kişiler, peygamberler, din büyükleri gibi geniş halk kitlerinin ilgisini çekmek için genellikle "Hollywood film kalıpları" içerisinde yansıtılmıştır. ${ }^{35}$ Dinsel filmleri, Türk sinemasının o dönemlerde içinde bulunduğu büyük bunalım karşısında ne yapacaklarını şaşıran sinemacıların başvurduğu Özön'ün "din ticareti”" ${ }^{36}$ olarak tanımladığ ${ }^{\prime}$, Yenen'in ise "Ticari Kazanç Aracı Olarak Din" ${ }^{37}$ olarak değerlendirdiği bu tür filmlerin bazı açılardan yapımcılara avantaj sağladığı ifade edilebilir. Öncelikle Anadolu insanının hassas dini duygularının menfaate çevrilmesi yoluyla bir pazar oluşturma amacı söz konusudur. Zira derme çatma dekorlar, uydurma giysiler, özensiz derlenmiş figüranlarla son derece ilkel biçimde çekilen bu filmlerin, maliyetleri de oldukça düşüktür. Aynı dekor, giysi ve oyuncularla aynı tarz çok sayıda film çekmek mümkündür. Konu sıkıntısı da "kısas-1 enbiya"lardan birçok senaryo çıkarmakla aşılmıştır. Bu durumdan istifade etmek isteyen bazı yapımcılar da bu tür filmlerin ilgi görmesi üzerine Mekke, Bağdat ve Şam gibi önemli kentlerdeki kutsal mekânların görüntüleri ile İstanbul cami ve türbeleri, Konya Mevlana Müzesi ve Şanlıurfa Halil İbrahim Camisi'nin görüntülerini bir-

33 Yaylagül, Levent, "1960-1970 Dönemi Türk Sinemasında Düşünce Akımları", Sinemada Anlatı ve Türler, F. D. Küçükkurt - A. Gürata(Ed.), Vadi Yayın, Ankara, 2004, s. 266-268.

34 Yenen, a.g.e., s. 52-53.

35 Özön, Nijat, Sinema Sanatına Giriş, Agora Kitaplı̆̆ı, İstanbul, 2008, s 211-212.

36 Özön, a.g.e.

37 Yenen, a.g.e. 
leştirerek meydana getirdikleri filmlerde Kâbe sahneleri kullanarak diğer Müslüman ülkelere satma başarısı da göstermişlerdir. ${ }^{38}$ Ticari açıdan seyircilerin dini duygularından istifade etmeyi amaçlayan bu tür filmler, "dini film” olarak tanımlansa da milliyetçilik vurgulu diğer tarihi filmlerle benzerlik göstermektedirler. Çünkü hikâyelerin, inanan Müslüman iyilerle, inanmayan kâfir kötüler arasında kurgulanması sebebiyle kişilikler ve olaylar İslam tarihinin fantazyaya dönüştü$\breve{g u ̈ ~ a r k a i k ~ b i r ~ s i n e m a ~ d u ̈ n y a s ı n d a n ~ s e s l e n e n ~ m i t o l o j i k ~ k a h r a m a n l a r a ~ d o ̈ n u ̈ s ̧ m e k-~}$ tedir. Olayların duygu ve gerçeklikten uzaklaştırılarak masalsılaştırılan bir dille aktarılması, dinin tecrübe edilen günlük hayatla ilişkisinin bulunmadığı dünya tasavvuruyla eski zamanlara ait bir gelenekle özdeşleştirilmesine yol açmaktadır. İnsanların karşılaşabileceği sorunlara pratik çözümler üretmeyen menkıbe işlevi gören dinsel filmler, Müslüman olmanın erdemlerini hatırlatan ama İslami hayat tasavvurları ve meselelerinden yoksun bir yapıda ortaya çıkmışlardır. ${ }^{39}$ Dinsel (hazretli) film türlerinde senaryolar tamamen tarihsel karizmatik dini şahsiyetler üzerine kurgulanmaktadır. Bu durum dinsel bir öykünün, toplum tarafından kabul görmüş dini bir şahsiyetin hayatı bağlamında anlatılmasının kolaylığı yanında sinema sektörünün oluşturduğu film kahramanları yoluyla canlılığını devam ettirmesiyle de ilişkilendirilebilir. Bir yapıtın sinema hüviyetine dönüşmesi için sinemasal mantık ve retoriğin oluşturulması gerekmektedir. Dinsel filmler, din ve din ile ilgili unsurların aktarımında kullandıkları basit teknikler dolayısıyla "ilkel simgecilik" kavramıyla değerlendirilebilir. İlkel simgecilik kavramı, anlatılmak istenilen bir olayın genel bütünlükten yoksun olarak simgelere verilen aşırı önemi ifade etmek için kullanılır. ${ }^{40}$

Milli Sinema akımı, 1970 yılında "Birleşen Yollar" filmi ile başlayan ve en son örneğini "Hür Adam" (2010) filmi ile beyaz sinema, muhafazakâr sinema, İslamcı sinema, İslami sinema gibi kavramlarla tanımlanmaya çalışılan; kültürel kaynak olarak dini (İslam) bir tez olarak sinemaya taşımayı amaçlayan ve Yenen'in dini temaları kullanma biçimine göre değerlendirdiği ve "Kültürel Bir Tez Olarak Din" ${ }^{41}$ şekilde ifade ettiğ Türk Sinema akımıdır. Milli sinema kavramının bir akım haline gelmesinde en büyük etkenin Milli Türk Talebe Birliği (MTTB) bünyesinde faaliyet gösteren "MTTB Sinema Kulübü” olduğu söyle-

38 Candemir Özden, Türk Sinemasında Dini Filmler, (Yayınlanmamış Yüksek Lisans Tezi), Anadolu Üniversitesi Sosyal Bilimler Enstitüsü, Eskişehir, 1986, s. 19.

39 Maktav, Hilmi, "Kur'an'dan Kurama İslami Sinema", Modern Türkiye'de Siyasi Düşünce (İslamcılık), Cilt: 6 , 2. Bask1, İletişim Yayınları, İstanbul, 2005, s. 991.

40 Wollen Peter, Sinemada Göstergeler ve Anlam, 2. Baskı, (Çev Bülent Doğan, Zafer Aracagök), Metis Yayınları, İstanbul, 2004, s. 147.

41 Yenen, a.g.e., s. 62. 
nebilir. MTTB'nin milli sinema akımındaki rolü, Türk Sinematek Derneğinin devrimci sinema üzerindeki rolü ile benzerlik göstermektedir. Nasıl ki devrimci sinema fikrine sahip sinemacılar bu dernek etrafında birleşmişler ve düşüncelerini olgunlaştırmışlarsa milli sinema fikri de MTTB etrafında toplanan sinemacılar tarafından olgunlaştırılmıştır.

Milli Sinema akımını "İslami Sinema" kavramı ile tanımlayan Maktav'a göre, bu sinema akımı gücünü Türkiye'deki İslami düşüncenin yükselişinden almakta ve söz konusu filmlerin "teblĭg" misyonu üstlenerek kendisini Kemalist modernleşmeye karşı konumlandırmıştır. Bu durumda geçerli ve güncel olanın kodları ile iz süren Milli Sinema, her ne kadar Türkiye'deki sekülarizasyon savunucuları tarafından endişe ile karşılansa da tıpkı kendisine aidiyet atfettiği siyasi anlayış gibi pragmatist bir tutum içinde var olmuş, varlık nedeni reddettiği şeyden öteye geçememiş ve bu tutum sinema diline de zafiyet olarak yansımıştır. ${ }^{42}$ Milli Sinema akımının Türk Sinema Tarihi içerisindeki önemi, yönetmenlerin filmlerinde açık veya sembolik düzeyde İslam'a ilişkin atıflarından kaynaklanmaktadır. Neticede din, Türk toplumunun karakterini oluşturan birincil etkendir ve beyazperdede "tez" olarak kullanılmaktadır. İslam'ın sinemada "tez" olarak kullanılmasından maksat, iki yüz yıldır batılılaşma serüveninde doğu-batı karşıtlığı üzerinden aidiyet sorunu yaşayan Türk insanının ancak İslam dini ile sağlıklı bir çözüm geliştirebileceği düşüncesidir. Bu düşüncenin sinemada örnekleri ise Milli Sinema filmleri olarak adlandırılmaktadır.

Modernleşme sürecinde Tanzimat'tan itibaren devam ettirilen tartışmalar, daha çok dinin ilerleme ve çağdaşlaşma karşısındaki konumu üzerinde yoğunlaşmıştır. Çünkü "kökten batıcı cumhuriyet seçkinleri", dini, bir iktidar aracı olarak tanımlamış ve belirli vurgularla tanımlanan bu din anlayışını merkezde tutarak hedef seçilen çağdaş medeniyetler seviyesine ulaşma çabalarında dini "çağdaşlaşma karşıtı" bir konuma indirgemişlerdir. ${ }^{43} \mathrm{Bu}$ karşıtlık ise dine atfedilen iki özellik dolayısıyla ortaya çıkmıştır. Birincisi dinin gerçek işlevinden uzaklaşarak "bidat ve hurafelerle kuşatılması", ikincisi ise dinin "siyasal amaçlar" için bir araç haline getirilmesidir. Türk sinemasında birçok ilki gerçekleştiren ve aynı zamanda sinema sanatının Türkiye'de gelişmesine engel olmakla suçlanan Muhsin Ertuğrul, Cumhuriyetin modernleşme projesini benimsemiş bu doğrultuda filmler üretmiştir.

Yenen, "Geleneksel Türk Sineması" olarak adlandırdığı 1960-1996 yılları arasında yapılan filmlerde ise din, dindarlık ve din adamı konularının "daraltılmış"

42 Maktav, a.g.m., s. 989.

43 Kilıç, a.g.m., s. 21. 
bir bakış açısıyla değerlendirmektedir. Yenen, Geleneksel Türk Sineması'nın popüler filmi örneklerinde ise din, köy ve köylülük ile ilgili bir olgu şeklinde ortaya çıktığını, dindarlı̆̆ın da "köy ve gecekondu dindarlığ likler taşıdığını ifade etmektedir. Bunlar; kurban bayramı, adak kurbanı, kurban edilecek hayvanın süslenmesi, muska, imam nikâhı, imam nikâhı sırasında anahtar ve bıçak kullanmak, kurşun dökülmesi, yedinci ve kırkıncı günlerin kutsall1ğ1, cenaze töreni, yeni doğmuş çocuğun kulağına ezan okumak, yağmur duası, başlık parası duası, bel büyüsü, kurban olarak horoz kesilmesi, Müslüman bireyin mutlaka bir tarikata intisap etmesi ve doğru yolu bulabilmesi için bir şeyhe bağlı bulunması, köylünün imam veya ağanın kulu olması, dini açıdan "teknik ve medeniyetin günah" olarak algılanmasıdır. ${ }^{44}$ Yenen ayrıca gecekondu dindarlığının iki boyutuna dikkat çeker. Birincisi, köy şartlarında sahip olunan inançlara sıkıca bağlı kalmak, ikincisi ise göç edilen şehrin değerlerini benimsememe konusunda bilinçli bir direnç göstermektir.

Yeni Türk sinemasında ise din, sinema açısından "kabullenilmiş" bir sosyal gerçeklikle temsil edilmektedir. Bu durum, şiddet, terör, modernleşme, gündelik hayat gibi sosyal ve kültürel konuların dini bağlamda incelenmesiyle anlaşılmaktadır. Ayrıca ilk dönem ve geleneksel Türk sinemasındaki din adamı tiplemeleri yerlerini sosyal aktörler olarak karakterlere bırakmaktadır. Yeni Türk sinemasında din adamları farklı özellikleri itibariyle temsil edilmeleri açısından "din adamı tipolojisi" oluşturmaya imkân vermektedir. Yine dindarlık tipolojisi de kentlilik olgusuna uygun bir şekilde "kent dindarlığı" olarak ortaya çıkmaktadır. ${ }^{45}$ Yüzyılı aşkın bir tarihe sahip Türk Sineması, her ne kadar farklı dönemselleştirmelere ayrılsa da ele aldığ konular genel olarak benzerlikler göstermektedir. ${ }^{46}$ Bu konuların önde gelenleri ise bir şekilde din, din adamı ve dindarlığa ait temsillerdir. Dolay1sıyla din konusu veya dini temsiller Türk Sineması'nda incelenmesi, anlaşılması ve kavranması gerek başat unsurlardır.

\section{Sonuç}

Türk Sineması yaklaşık yüzyıldır toplumsal hayatımızı perdeye taşımaktadır. Bu süre içinde pek çok tema arasında gerek doğrudan gerekse dolaylı olarak dini imgelerde bir şekilde sinemada konu edilmektedir. Sinema, her ne kadar devlet tarafından ihmal edilmiş olsa da sinema yapımcı ve yönetmenleri -az saylda alternatif girişim dlşında- genelde hakim siyasal atmosfere uygun filmler üretmeyi ter-

44 Yenen, a.g.e., s. 200.

45 Yenen, a.g.e., s. 200.

46 Tunali, a.g.e., s. 174. 
cih etmişlerdir. Bu hakim siyasal atmosfer ise doğal olarak Cumhuriyet'in resmi ideolojisidir. Muhsin Ertuğrul'un başlattığı Türk Sinema geleneği pek çok açıdan günümüze kadar devam ettiği gibi din imgelerin ele alınma biçiminde de devam etmiştir. Dönemsel olarak farklılıklar göstermekle birlikte din genelde modernleşme sürecinde hiç de hak etmediği halde gelenekle özdeşleştirilerek, modernleşme karşıtı ve olumsuz bir unsur olarak filmlerde yer almıştır.

Yaklaşık bir tahminle 10.000 civarında bir sayıya ulaşan Türk Sinema filmleri her ne kadar dönemsel farklılar gösterse ve yönetmenlerin öznel bakış açılarıyla şekillendirmiş olsa da dönemin toplumsal, kültürel, ekonomik ve siyasal yapısını yansıtan zengin bilgiler içerebilmektedir. Dolayısıyla Türk film arşivi, yakın tarihin sağlıklı bir tahlilini yapmak için muazzam bir imkân barındırmaktadır. Sosyal bilimler için değerlendirmeyi bekleyen bu arşivler, daha spesifik ve derinlikli çalışmalara konu edilebilir. Bu bağlamda din imgesi özelinde yapılacak daha ayrıntılı ve daha derinlikli çalışmalar, yakın geçmişin daha sağlıklı bir biçimde değerlendirilmesi için yararlı olabilir.

\section{Kaynakça}

Abisel, Nilgün, Türk Sineması Üzerine Yazılar, İmge Kitabevi, Ankara, 1994.

Candemir Özden, Türk Sinemasında Dini Filmler, (Yayınlanmamış Yüksek Lisans Tezi), Anadolu Üniversitesi Sosyal Bilimler Enstitüsü, Eskişehir, 1986.

Coşkun, Esin, Türk Sinemasında Akım Araştırması, Phoenix Yay., Ankara, 2009.

Daldal, Aslı, 1960 Darbesi ve Türk Sinemasında Toplumsal Gerçekçilik, Homer Kitapevi, İstanbul, 2005.

Güçhan, Gülseren, Toplumsal Değişme ve Türk Sineması, İmge Kitabevi, Ankara, 1992.

Heper, Metin, Türkiye'de Devlet Geleneği, 3. Baskı, Doğu Batı Yay., Ankara, 2010.

Kaplan, Neşe, Aile Sineması Yılları 1960'lar, Es Yayınları, İstanbul, 2004.

Kara, İsmail, Cumhuriyet Türkiyesi'nde Bir Mesele Olarak İslam, Dergâh Yay. İstanbul, 2008.

Karakaya, Handan, Türk Sinemasında Din Adamı Tiplemesi, (Yayınlanmamış Yükssek Lisans Tezi), Fırat Üniversitesi Sosyal Bilimler Enstitüsü, Elazığ, 2008.

Karpat, Kemal. H., İslam'ın Siyasallaşması, Bilgi Ü. Yay., İstanbul, 2004.

K1lıç, Ahmet Faruk, "Cumhuriyet'in İlk Yıllarındaki Din Politikalarının Şifresi”, http://www. dem.org.tr/dem_dergi/2/dem2mak3.pdf, (Erişim: 15.02.2015), 2007.

Kırel, Serpil, Yeşilçam Öykü Sineması, Babil Kitap, İstanbul, 2005.

Kuyucak Esen, Şükran, Türk Sinemasının Kilometre Taşları, Agora Kitap, İstanbul, 2010.

Maktav, Hilmi, "Cumhuriyet'in Sinemacısı Muhsin Ertuğrul", Tarih ve Toplum Dergisi, Kasım, Say1: 227, İstanbul, 2002.

, "Kur'an'dan Kurama İslami Sinema", Modern Türkiye'de Siyasi Düşünce (İslamcllık), Cilt: 6 , 2. Bask1, İletişim Yayınları, İstanbul, 2005. 
Halil UZDU / Illahiyat Fakültesi Dergisi • 5 - 2016・25 - 40

Monaco, James, Bir Film Nasıl Okunur, (Çev. Ertan Yılmaz), Oğlak Yayıncılık, İstanbul, 2011.

Özgüç, Ağah, Türlerle Türk Sineması, Dünya Kitapları, Sinema Dizisi, İstanbul, 2005.

Özön, Nijat, Sinema Sanatına Giriş, Agora Kitaplığı, İstanbul, 2008.

Öztürk, Serdar, Erken Cumhuriyet Döneminde Sinema-Seyir-Siyaset, Elips Kitap, Ankara, 2005.

Scognamillo, Giovanni (2003), Türk Sinema Tarihi, 2. Bask1, Kabalcı Yayınları, İstanbul, 2003.

Tunal, Dilek, Batıdan Doğuya, Hollywood'dan Yeşilçam'a Melodram, Aşina Kitaplar, Ankara, 2006.

Uçakan, Mesut, Türk Sinemasında İdeoloji, Düşünce Yayınları, İstanbul, 1977.

Yaylagül, Levent, "1960-1970 Dönemi Türk Sinemasında Düşünce Akımları", Sinemada Anlatı ve Türler, F. D. Küçükkurt - A. Gürata(Ed.), Vadi Yayın, Ankara, 2004.

Yenen, İbrahim, Toplumsal Tezahürleri Bağlamında Türk Sinemamsında Din Dindarlık ve Din Adamı Olgusu, (Yayınlanmamış Doktora), Tezi, Anakara Üniversitesi Sosyal Bilimler Enstitüsü, Ankara, 2011.

Wollen Peter, Sinemada Göstergeler ve Anlam, 2. Bask1, (Çev Bülent Doğan, Zafer Aracagök), Metis Yayınları, İstanbul, 2004. 